IDENTITIES Vol. 10 / No. 2

The Post-Human, the Non-human and its Political Revolt 


\title{
The liberal mind and its mutants
}

\section{Tomasz Sikora}

Assistant Professor, Pedagogical University of Cracow

(tsikora@ap.krakow.pl)

\begin{abstract}
:
The following observations have been occasioned by the 2011 Marvell comic adaptation X-Men: First Class. Rather than a comprehensive analysis of the movie, however, the essay is a collection of more general observations on the modern "liberal mind" and how it imagines and structures community, difference and the political itself. One of my central claims, drawing on the work of Roberto Esposito, is that the modern model of liberal humanism has developed largely in terms of what he calls the "immunization paradigm." In this model, the inclusion of difference into the political may be interpreted in terms of immunization: a body politic internalizes a certain amount of what seems to constitute a danger in order to immunize itself against that very danger. Present-day liberalism differs from its earlier forms in that it recognizes the idea of difference and folds it into its own projections of a "common good." But not all forms of difference are equally welcome, and the liberal regime maintains its hegemony by bargaining some kinds of difference against others. One of the key questions for the present, therefore, is which kinds of difference the dominant regime considers more worthy of life and legal protection, and which other kinds are implicitly considered less worthy or, indeed, deserving extinction.
\end{abstract}

Keywords: liberalism, difference, community, immunization, X-Men

\section{The liberal mind}

Although set during the Cuban Missile Crisis in 1962, X-Men: First Class (dir. Matthew Vaughn) is a movie immersed in the political debates that have been animating American and, more generally, Western societies in recent years. One finds, for instance, an obvious allusion to the "don't ask, don't tell" rule that applied to US army personnel before it was lifted by Barack Obama several months after the release of the movie; the allusion occurs when, in response to his CIA boss's surprise, Hank McCoy says innocently: "You didn't ask [whether I was a mutant], so I didn't tell." The issue of the legitimacy of the use of torture on whoever happens to be classified as an "enemy of the state" is invoked as well when one of the CIA directors argues, with remarkable sophistry, that although the law prohibits the use of torture, it certainly intends to prohibit its use on human beings only, not on mutants. Thus, the movie points to the (neo-Schmittian) question of the state's prerogatives in defining the (deadly) enemy and undertaking necessary steps for the protection of the nation's security. While in 1962 the Cold War logic may have defined the United States' (as well as, to be sure, liberty's and democracy's) enemy in a rather unambiguous way, that kind of binary logic is certainly shown in the movie to be much more problematic in the times of a "global war on terror." True, Dick Cheney still played on that simple binary ('us' versus 'them') thinking when he proclaimed: "Just as surely as the Nazis during World War Two and the Soviet communists during the Cold War, the enemy we face today is bent on our destruction"; ${ }^{1}$ but as George Bush Sr. noticed in support of his son's anti-terrorist policies, in the past "we knew who the enemy was and we knew what we had to do to get rid of them" whereas "the enemies we face today are [...] shadowy. They are a terrible new problem."2

\footnotetext{
$\overline{1}$ Dick Cheney, Speech at the Republican National Convention, September 1, 2004 (http://www.pbs.org/newshour/vote2004/repconvention/ speeches/cheney.html).

2 "Bush's father outlines son's tough challenges," Washington Times, October 22, 2002 (http://www.washingtontimes.com/news/2002/ oct/22/20021022-093322-2942r).
} 
My starting point is that $X$-Men: First Class may be approached as exposing the intricacies of the (post)modern liberal mind. My use of "liberal" here is rather broad, I admit, and it does not do justice to the differences between European and US usage, nor to the multifariousness of what "liberal" may actually stand for, philosophically and/or politically. In fact, my terminological nonchalance goes so far as to blur the distinction - so fundamental, many would claim, for the contemporary political landscape - between "liberal" and "conservative." (I leave aside another problematic issue, i.e. the relationship between "leftist" and "liberal.") Not that I deny the obvious fact that at some level the discursive differences exist and organize, in a bipolar manner, much of the contemporary political scene; after all, conservatism is often posited (and posits itself) as precisely opposed to liberal modernism. I would argue, however, that at a "deeper" level, liberalism or, better, liberal humanism names a more general framework (as part of the paradigm of "universal modernity") that effectively limits the horizon of possible or at least "realistic" politics nowadays. In other words, I take "liberalism" to stand for the ideological legitimization of the contemporary capitalist world order as well as a hegemonic discourse based on a set of axiomatic beliefs - not necessarily internally coherent - concerning "reality," "(universal) human nature," "subjectivity," etc. This discourse structures contemporary political positions beyond any particular partisan divisions by determining a horizon of the possible. (One may recall here, for instance, Lee Edelman's "reproductive futurism" ${ }^{3}$ as a structuring, goes-without-saying principle of any political grammar today; I would see reproductive futurism as one of liberal humanism's axioms.) The discourse makes claims such as: "We're all human, after all, and so we all want $X / Y$ / Z." One simple example from the end of the Cold War era may be found in the lyrics of Sting's 1985 song which said: "We share the same biology / Regardless of ideology / Believe me when I say to you / I hope the Russians love their children too."

Let me stress, however, that the liberal-humanist idea of a shared universal human nature does not preclude constant production of dehumanized enemies: by not adhering to certain standards, some individuals (and/or whole populations) allegedly dehumanize themselves - cut themselves off from "common humanity" - and thus justify their own extermination. While this kind of dehumanization or demonization of the enemy is more readily attributed to "conservative" positions, it is no aberration to the liberal mind, either, as Mark Neocleous makes clear. ${ }^{4}$ Liberal humanism, says Neocleous, first devises a common human nature, based on selected meanings of "freedom" and apparently blind to markers of difference such as race, gender, sexuality, religion etc., only to exclude, sometimes brutally, all those who fail to meet specifically defined standards of humanity; that's why, for instance, liberal-minded Europeans did not, as a rule, oppose the extermination of Native Americans, who clearly failed to recognize the "fundamental human value" of free trade. Over the last decades, liberal humanism has folded some of the markers of difference into its understanding and practice of the political, but even when politicized, difference remains more like "stylistic variations" added to an otherwise unchallenged liberal grammar.

I see liberal humanism, then, as a general (seemingly $a$ - or postpolitical) framework for any "possible" political projects as well as an ideological alibi for capitalism and its (neo)colonial expansion. I do not mean to simply conflate liberalism and conservatism, but I do mean to suggest, following the work of Mark Neocleous and some other political thinkers, that the difference between them is one of scale rather than essence. (Indeed, leaders such as Margaret Thatcher and Ronald Reagan were perfectly capable of combining extreme social conservatism with extreme economic (neo) liberalism - both in the name of nothing less than "freedom," of course). The scale refers, in the first place, to the state's readiness to use "sheer force" - i.e. the executive power's prerogative to employ "special measures" - when "necessity calls," i.e. when faced with a "high security risk." What actually constitutes that security risk will, of course, fluctuate historically and across the political spectrum, but not the presumed legitimacy of the actions undertaken, allegedly, to protect the nation's security. ${ }^{5}$ Conservatives seem much less sentimental about the use of force, even if they tend to dress their rhetoric in high-flown, moralistic clichés. Liberals, on the other hand, usually need more justifications, more invocations of legal procedures, more "humanitarian" rhetoric (the protection of human rights etc.); they will use force only as the "very last resort." One way or another, the "liberal humanism" that I am so hastily trying to sketch here, i.e. a framework that in fact encompasses both "conservatives" and "liberals," makes (neocolonial) claims to a moral superiority - or, perhaps, a vital/ zoetic superiority - which justifies any action aimed at self-protection and self-preservation. US conservatism and US liberalism play the respective parts of the bad and good policeman, both working for the very same neocolonial, capitalist-humanist cause.

\footnotetext{
3 See Lee Edelman, No Future: Queer Theory and the Death Drive (Durham: Duke University Press, 2004).

4 See Mark Neocleous, "War as Peace, Peace as Pacification," Radical Philosophy 159 (2010): 8-17.

5 "Security," Neocleous asserts, "becomes the cornerstone of the liberal mind, which identifies security with the freedom and liberty to pursue one's individual self-interest." Mark Neocleous, Critique of Security (Edinburgh: Edinburgh University Press, 2008$), 26$.
} 


\section{In search of the enemy}

X-Men: First Class exemplifies, among other things, the ethical dilemma around defining and dealing with the "enemy," i.e. protecting the communal "self" against dangerous foreign bodies. On the ethical (and, indeed, crypto-religious) level, the movie can be read as a story of overcoming the Old Testament ethics of retribution with the Christian ethics of forgiveness, however secularized forms these ethical stances may assume in the political theatre today. It is quite ironic that Erik Lehnsherr, a Holocaust victim, eventually adopts the methods of his Nazi oppressor, doctor Schmidt vel Sebastian Shaw (might that be a veiled criticism of Israel's policies in Palestine?), such that the assassination of the exNazi turns out to be Erik's personal revenge rather than a service to the human race, even if it actually helps prevent a nuclear war, incidentally. Evil may not be posited here as some transcendental, Manichean force (Erik/ Magneto's motivation is psychologically understandable and the viewer cannot but feel sorry for him), but it is certainly contagious and always generates more evil as it keeps propelling the vicious circle of violence and revenge. For the liberal mind, it is not only imperative that there be a future, as Edelman has demonstrated, it is equally imperative that there be a better future, a future with "less evil."

Magneto's ethical attitude is overcome by "good" Professor Xavier, who represents an essentially liberal vision of the "common good." Liberal, that is, insofar as it lays claims to a rationally determinable universal goodness (shared, apparently, by humans, posthumans and nonhumans) that leaves no room for any active dissent; if any, dissent can only be conceived of as based on plain error or unamastered negative affects. To put it simply, his ethic comes down to the Christian idea that one should hate the sin, not the sinner (that is why, for instance, the Catholic catechism condemns homosexual acts, but prescribes respect for "homosexual persons"). In this way the enemy becomes more abstract: it is not Shaw himself, not Russians, but evil itself, conceived of as a kind of cancer that may develop anywhere anytime, even in ourselves. It is against this evil that the modern body politic must guard, or immunize, itself. While partly justified to act as he does due to his childhood trauma, Magneto is not able to recognize and protect himself from the evil that took root in his own nature, he cannot rise above his personal resentment and break free from the vicious circle of evil. Unlike him, as the movie suggests, the two hostile superpowers were ultimately able to do so: just minutes away from a nuclear confrontation in 1962 (and at other times), they managed to avoid a nuclear disaster and eventually terminated the crazy arms race; they now, more or less, work together for "humanity's common good," because, believe me, "Russians love their children too" (or, in Edelman's terms, they desire to have a future, and a better one at that). Liberal democracy's main question, then, seems to be not so much WHO the enemy is any more, as WHAT the enemy (or poison, or disease) is, the common enemy of "us all." This enemy, this cancer, may develop in the very midst of us, inside us, and so every effort must be made to prevent it, to identify the dangerous germ in due time, to neutralize the evil before it eats to the heart of (universal) humanity. Humanity must be laboriously monitored, protected and corrected lest it degenerate into an apocalyptic pathology beyond any cure.

What I am saying, in effect, is that conservatism and liberalism may, to some extent, be distinguished on the basis of how they deal with problems of security, a difference that stems partly from relatively different conceptualizations of "community." At the same time, however, conservatism will not abstain from using the "liberal" rhetoric of, say, protecting the rights of women (as well as, increasingly, of gays and lesbians) in order to morally justify military interventions in "barbarous" (often Muslim) countries, whereas liberals will ultimately buy into the "state of emergency" rhetoric that justifies half-legal or illegal use of bare force. Take Obama. Liberal as he may be in some respects, at least by American standards, when it comes to "national security" it is business as usual. The 44th president will go to any lengths to present himself as a staunch defender of the American people and the American way of life, not the liberal softy his opponents may try to make of him. On issues of security he will not compromise. Consequently, he was quick to condemn and prosecute Chelsea (Bradley) Manning for bringing about an alleged security risk to the US army and the nation by transferring a massive amount of classified information to WikiLeaks (and now he continues to defend Chelsea's treatment in military detention, even after it was found "excessively harsh" by the military judge presiding over Manning's court-martial). More spectacularly, Barack Obama will be remembered for his "success" in having Osama bin Laden tracked down and assassinated. In the last instance, then, physical elimination has not really been removed from the political toolbox of liberalism: it is the disease (of, say terrorism) we try to prevent and cure, for sure, but some individuals still prove to be living embodiments of that very disease and so - to stop the contagion from spreading - they should be eliminated.

While in the US bin Laden's death was, expectedly, met with general euphoria and the feeling of "justice finally done," some European politicians expressed their doubts. After Angela Merkel announced she was "pleased" about bin Laden's death, Siegfried Kauder, a member of Merkel's own Christian Democratic Party, responded: "These are 
revenge fantasies one shouldn't indulge in. That's the Middle Ages." ${ }^{\prime \prime}$ Indeed, most experts (for what they are worth) agreed that the execution did little to fight the "real evil" itself, terrorism, and had a propagandist impact at best. Contrary to Obama's actions, X-Men: First Class clearly warns against the mistake of identifying the disease with the person (or, indeed, a whole population): terrorism is the enemy of all humans: Christian, Muslims or otherwise. After Americans and Russians (who, let me stress, are shown in the movie to behave in an almost identical manner) avoid a military confrontation, both sides come to believe that they have finally found the true, common, embodied enemy: the mutants. But the film instructs us that the evil lies elsewhere and rather than seek the physical elimination of this or that population, "we all," across populations and social groupings, should concentrate on curing the cancer that threatens all of us equally, because it threatens humanity's very essence.

Ridley Scott's Kingdom of Heaven (2005) may serve as a good illustration of how the liberal mind narrates its own nascence out of the "dark ages" that Siegfried Kauder alluded to apropos of the assassination of bin Laden. Two conflicting ethics, both of which would claim to be Christian, are juxtaposed in the movie: the "pagan" (or Old Testament) Christianity of characters such as Guy de Lusignan or Sibylla and the (proto)modern, relativized Christianity of the protagonist Balian. (The conflict corresponds, roughly, to that between Magneto and Xavier in X-Men.) Here, the evil "other" is not simply the Muslim, but rather the unenlightened Christian, who conceives of community simply in terms of "us" versus "them." The modern Christian, on the other hand, is a self-critical and doubtful Christian, pragmatic and anti-fundamentalist. Were we to follow Žižek's provocative propositions, we could go as far as to say that the best embodiment of modern Christianity is to be found in an atheist. ${ }^{7}$ For enlightened Christianity, as well as its lay version - liberalism, Christian fundamentalism is nothing but (neo)paganism, whereas for "fundamentalists" relativized Christianity betrays the religion's essence. For the modern universalist Christian every human being is savable and therefore merits life (rather than elimination); every person should get the chance to become a good Christian / a good (normativized) citizen: he or she just needs to be "cured" and assimilated. Any potential enemy is simply mistaken, simply needs to be re-educated or converted. Thus every person on Earth is always already potentially Christian or liberal even before they know it. A universalist "common good" is posited here; to be against it is to be against humanity as such. The "pagan" version of Christianity (and the conservative politics that is believed to derive from it) is much more prone to eliminate potential enemies, if not physically, then at least symbolically. To sum up, if you are an infidel and you insist on being one, you will be either "tolerated" and, if need be, quarantined and institutionalized (in the enlightened version) or eliminated (in the pagan version). Unless, that is, you are identified as a vital threat to the community's security, which justifies your annihilation no matter what.

I do not necessarily subscribe to this genealogy (as seen in both movies) that the liberal mind has devised for itself in order to distinguish itself from conservatism, and more particularly to distance itself from any possible links with fascism. This discursive distinction between "pagan/ barbarous" and "modern/ enlightened" is true inasmuch as it creates real political and social effects, but it obscures the deeper ways in which liberalism and fascism are implicated in each other: not only was fascism, in many ways, a thoroughly modernist project, but also liberal humanism proved perfectly capable of accepting the colonial extermination of whole indigenous populations. (Admittedly, the ideas stemming from liberal humanism - particularly universal human rights-have also been used to oppose and combat colonial atrocities, especially when they became too public, too gory, or too offensive for refined liberal sensitivities.) I would rather delineate the genealogy along the lines of Roberto Esposito's elaboration on Foucault's analysis of modern technologies of power. I would thus claim, following some insights from Esposito, that the modern model of liberal humanism has developed largely in terms of what he calls the "immunization paradigm."

\section{Immunoliberalism}

Much of what I have said so far calls for an immunological reading. Particularly, when I noted the shift from an embodied/ WHO-enemy to the disembodied/WHAT-enemy, I was pointing towards modernity's shift towards the immunological paradigm. Identifying and eliminating, or at least neutralizing, a possible danger is what the immune system is precisely supposed to do. It may be easier to eliminate a contagious foreign body-a whole living organism-in order to prevent an epidemic, but in the increasingly medicalized modern world the tendency is rather to control and quarantine such a body and, if possible, find a cure for the disease carried by that body (or else make the disease useful in some way).

This seems to be a safer method of protection in the long run, as dead bodies may prove more difficult to handle than living ones, while an effective cure solves the problem once and for all. Hate the disease, not the diseased person.

\footnotetext{
${ }^{6}$ Quoted in Michael Steininger, "What's the Fuss over Angela Merkel's bin Laden Comment?," The Christian Science Monitor, May 5, 2011

(http://www.csmonitor.com/World/Europe/2011/0505/What-s-the-fuss-over-Angela-Merkel-s-bin-Laden-comment).

7 Slavoj Žižek, "Why Only an Atheist Can Be a True Christian," lecture delivered at Wilson College, Princeton University, on October 12, 2010

(http://www.youtube.com/watch?v=Gx3_2lpvZKM).
} 
This shift towards an immunological understanding (and regulation) of bodies and bodies politic stems mostly from the fact that modernity's liberal humanism has gradually developed a much more nuanced account of externality and internality, self and non-self, as well as the border that supposedly separates them. The modern regime has recognized that the dividing line remains eternally unstable, that borders are (and must be) permeable, that the internal needs the external to survive, whereas modernity's conservatism adheres to a more rigid distinction between the external and the internal. Conservatism does recognize the risks of an internal destabilization of order and a consequent anarchization, of course, but it is liberal humanism that has truly "discovered" internality (in the form of, for instance, psychology) and made the exploration and regulation of that internality its primary goal. A well-coordinated immunity system is expected to regulate the (political) organism's life from within; Esposito defines immunization as the (communal) organism's internal mechanism which protects it not by "frontal opposition" but through the strategy of "exclusionary inclusion or exclusion by inclusion." ${ }^{\prime \prime}$ The (conservative) idea of the border between self and non-self as simply marked by the limits of one's skin still remains relevant, no doubt, but to the liberal mind it appears grossly insufficient. The real "drama" takes place at an internalized micro-level: it is the immunity system that must constantly differentiate self from non-self; identity is no longer the state of "being one with oneself," but rather the process of constant testing of the self's borders (scanning the system for viruses and glitches), discriminating between various elements and then ignoring, assimilating, destroying or neutralizing them, accordingly. "The immune system," as Edward S. Golub succinctly puts it, "must recognize self in some manner in order to react to something foreign."

The internalization or "absorption" of borders is thus one of the aspects of the shift towards the immunological understanding of communities. One example is the apparent "erasing" of borders within the European Union: the borders may have become more "virtual," but whenever the necessity occurs, in the face of an imminent threat, they quickly solidify back into place. On an everyday basis, borders - even if fragmented, diversified and projected into a myriad places - are routinely scanned by the state's functionaries for security/ immunity reasons. Indeed, the very fact that terrorism (unexpected strikes "from within" aimed at instigating panic and creating chaos) rather than more traditional war (large-scale army manoeuvres between countries) has now become a dominant mode of political militancy - the main danger to the "free world" of liberal democracies - testifies to the shift from the level of staterun war to protect (or expand) the territory to the level of shadowy and viral groups' actions that seek to destabilize the state's (sense of) security from within. It is now different, internalized and "pulverized" borders that have become potential or actual front-lines.

The (liberal) immuno-paradigm must be dynamic, intelligent, and self-learning in order to make the defense mechanisms effective. Where the static "conservative" paradigm focuses on integrity and sovereignty, the modern paradigm invests in operationality, functionality, and coordination. It is the "( $w)$ holiness" of (communal) bodies that the conservative paradigm seeks to preserve, as contrasted with the "healthiness" that the immuno-paradigm constantly monitors against any possible signs of pathology. (Healthiness, let us notice, is far from being a natural state in this perspective: it turns out to be the desired effect of constant monitoring and taking corrective measures in due time.) That health, wholeness and holiness are etymologically related is no trivial matter: it points to the deeper connection between the two apparently contradictory political orientations. The difference between them, let me repeat, is one of scale and (corresponding) method: elimination versus immunization, direct confrontation versus neutralization through partial or conditional inclusion. If, in the conservative paradigm, the role of the state is to defend an integral political organism through the direct opposition of an enemy, immunization, as Esposito has it, is "a negative [form] of the protection of life" ${ }^{10}$ whereby the body "defeats a poison not by expelling it outside the organism, but by making it somehow part of the body." ${ }^{11}$ It is important to see these two paradigms as not mutually exclusive, but rather as co-dependent and complementing each other in the task of keeping a modern body politic "alive and kicking."

\section{The uses of difference}

I have made the claim that X-Men: First Class is a classic product of the liberal-humanist mind and I have made Charles Xavier the bearer of the liberal ethics of forgiveness; for he is the one who fights evil with good, rather than with counter-evil. But have I not flattened that multidimensional character out too much? Isn't he, after all, a significant representative of difference? Is the whole movie not an affirmation of social difference as well as a critical reflection on the limitations and instabilities of the notion of "us-ness"?

\footnotetext{
8 Roberto Esposito, Immunitas: The Protection and Negation of Life (Cambridge, UK: Polity Press, 2011), 8.

9 Quoted in Donna Haraway, Simians, Cyborgs, and Women: The Reinvention of Nature (New York: Routledge, 1990$), 203$.

10

Roberto Esposito, Bios: Biopolitics and Philosophy. Minneapolis (University of Minnesota Press, 2008), 46.

11 Roberto Esposito, Immunitas: The Protection and Negation of Life (Cambridge, UK: Polity Press, 2011), 8.
} 
Indeed, the very idea of a mutant points to the question of difference: who is a mutant, after all: (still) a human being ("one of us"), or a posthuman/monster/renegade (NOT "one of us")? In an evolution of beings, how can we possibly determine the point of bifurcation where one species turns into another? What community, what us-ness should a mutant rightfully (want to) belong to? Whose "common good" is to be taken into account and how can it be defined at all? In a rather crucial moment of the movie, Professor Xavier concurs with Erik's opposition to the idea that "good" mutants should integrate into $\mathrm{ClA}$ structures. Instead, the mutants make a rather tenuous and equivocal alliance with the US government, while simultaneously building their alternative "sovereign" space, which by the end of the movie splits into Xavier's school on the one hand, and the underground kingdom of the separatist mutants led by Magneto, on the other. Thus, even the apparently good citizen Xavier opposes the politics of simple assimilationism. This refusal to be a functionary (of the state, an institution, an existing community, a nation), this problematization of "us-ness" on behalf of a different, emerging collectivity, seems crucial from the point of view of resistance strategies based on the politics of difference (including sexual difference).

Xavier's (but also Magneto's) stance poses the fundamental question of what is our cause. There are at least two challenges in this simple question: one is defining us-ness, and the other is determining a supreme political goal around which this us-ness will get organized and cemented. As outlined above, for the liberal-humanist mind the two models of community to choose from are the "fundamentalist" one that needs an embodied enemy as its very raison d'être, and the liberal one that postulates an open, civic society which follows different parameters of belonging and which is unified by a common good coinciding with a universal common good of humanity at large. Xavier situates himself, no doubt, closer to the latter position: regardless of any existing (and perhaps irreducible) differences, it is possible to work out common values and goals, such as world peace or preventing a global disaster. But, let us not forget, as a mutant he is not exactly human, thanks to which he can possibly slip away from the liberal logics of modernity and become a carrier of a different, mutated "life after liberalism."

In other words, this collaborative attitude on Xavier's part does not entail a neutralization of difference. More: by establishing his school, Xavier creates a foothold for a new society to come, a society where, most probably, homo sapiens will gradually disappear. Even though Magneto's separatism and ambition to gain hegemonic control of the world are censured in the film, Xavier's strategy does not entail a simple "inclusion" into the existing structures and/ or a pursuit of "equal rights"; rather, it seeks to build a coalition while continuing to carve out an alternative sociopolitical space. The "others" do not necessarily have to want to be equal (where equality is pre-defined and measured by existing standards). Magneto, as the one who essentializes difference too much, is placed on the side of "evil" (or at least "error"), whereas coalitional Xavier recognizes the values of liberal democracy, even if he continues to work, more or less secretly, on his own project. He acknowledges a certain "good" shared with human beings, but he also understands its historical limitations and refuses to stabilize one particular kind of "us-ness" into a fixed (if not, ultimately, fascist) political project. For him, "belonging" is not a straightforward notion: it is determined neither by a biological factor (being a mutant) nor by an essentialist "identity"; it is not reducible to one community nor to one totalizing political project.

This affirmation of difference, apparently postulated by the movie, becomes much more problematic when one takes a look, however cursory, at its racial politics, which immediately spurred a lot of controversy in the US. The most striking example is the black mutant Darwin, whose name connotes the idea of evolution, so crucial for the movie's conceptual framework. Darwin's early and unexpected death is an ironic comment on his name: the one who is rightly expected to prove adaptable and a model of survival skills, does not pass the natural selection process and is doomed to prompt extinction. The other characters possessing non-European features are not very positive (including Azazel, whose bright red skin must be read as an allusion to race, whether intended or not). Xavier's team, on the other hand, is made up of essentially white Caucasian mutants. The movie suggests, therefore, that the future, the better future, only exists for the unmarked, simply (super)human beings, and that some forms of difference are more noble than others (which is, after all, what the very idea of "natural selection" implies). Indeed, some recognized and appreciated forms of difference are being used by (post)modern regimes to denigrate other forms of difference. ${ }^{12}$ One example is

Israel's pinkwashing policy, i.e. creating the image of a liberal, tolerant Israeli state in opposition to the backward and intolerant population of Palestine. I have already mentioned the Western rhetoric that employs the idea of "women's

\footnotetext{
${ }^{12}$ Let me add that the movie is relatively pro-feminist, chiefly due to the woman CIA agent character. The character of Mystique merits a separate discussion. Although she seems to be the most radical proponent of an ethics of difference - one that claims each person is perfect just the way he/she is - she, paradoxically, epitomizes mimicry or the ability to imitate the most unique features of any individual. (In X-Men 2 she refuses to simply imitate a "normal human being" on a permanent basis because, as she says, "one shouldn't have to.") Besides, her "natural" blue skin returns us to the question of race. Tellingly, despite her debt of gratitude to Xavier, Mystique eventually decides to join Magneto.
} 
and gay rights" as a neocolonial, neoimperialistic measurement of civilizational progress, democracy and tolerance. Indeed, in some countries (particularly in the UK and, increasingly, in the US) even conservatives come to embrace the cause of "equal rights" for gays and lesbians, which they usually combine with exclusionary (e.g. anti-immigrant) policies in other areas. The net result is that queers' loyalty to the state is being purchased by providing them with "rights" (especially the right to marry), and simultaneously this bestowal of "legal rights" is used to demonize and exclude other "others" from the common good. It is processes such as these that have come under criticism in some recent queer theory under the general heading of "homonationalism." ${ }^{13}$

Present-day liberalism differs from its earlier forms in that it recognizes the idea of difference and folds it into its own projections of a "common good." But not all forms of difference are equally welcome, and the liberal regime maintains its hegemony by bargaining some kinds of difference against others. One of the key questions for the present, therefore, is which kinds of difference the dominant regime considers more worthy of life and legal protection, and which other kinds are implicitly considered less worthy or, indeed, deserving extinction. The inclusion of difference into the political may be interpreted in terms of immunization: a body politic internalizes a certain amount of what seems to constitute a danger in order to immunize itself against that very danger. "To survive," let me quote Esposito one last time, "the community-every community-is forced to introject the negative modality of its opposite, even if the opposite remains precisely a lacking and contrastive mode of being of the community itself." ${ }^{14}$ Radical difference, I would argue, is the liberal community's "negative modality." Under the liberal regime, difference must be administered in tolerable doses, it must be carefully regulated and made functional by and for the system. Arguably, these injections not only help immunize the system, but they also, slowly but surely, modify the community's internal modus operandi and allow the community to retain its evolutionary advantage. As in the Red Queen's kingdom from Lewis Carroll's Through the Looking Glass, where "it takes all the running you can do, to keep in the same place,"15 so in the (neo) liberal order socio-political relations need to change and readjust at an ever accelerating pace for the sake of keeping that very order in place. ${ }^{16} \mathrm{It}$ is this incessant labour of immunization and evolutionary competition (or arms race) that best illustrates the liberal-humanist (bio)political paradigm of the present time.

Tomasz Sikora is Assistant Professor at the English Department of the Pedagogical University of Cracow (Poland). In 2003 he published Virtually Wild: Wilderness, Technology and the Ecology of Mediation, and over the past ten years he has published widely in the areas of critical theory, queer theory and cultural studies. The several books he has co-edited include Out Here: Local and International Perspectives in Queer Studies (2006) and Towards Critical Multiculturalism: Dialogues Between/Among Canadian Diasporas (2011). He is also a co-founder and co-editor of the online journal of queer studies InterAlia.

\section{Bibliography:}

"Bush's father outlines son's tough challenges." Washington Times, October 22, 2002. http://www.washingtontimes. com/news/2002/oct/22/20021022-093322-2942r.

Carroll, Lewis. Through the Looking Glass. http://ebooks.adelaide.edu.au/c/carroll/lewis/looking/chapter2.html.

Cheney, Dick. Speech at the Republican National Convention, September 1, 2004. http://www.pbs.org/newshour/ vote2004/repconvention/speeches/cheney.html.

\footnotetext{
${ }_{13}$ For a discussion of homonationalism, see Jasbir Puar, Terrorist Assemblages: Homonationalism in Queer Times (Durham: Duke University Press, 2007).

14 Roberto Esposito, Bios: Biopolitics and Philosophy. Minneapolis (University of Minnesota Press, 2008), 52.

15 Lewis Carroll, Through the Looking Glass (http://ebooks.adelaide.edu.au/c/carroll/lewis/looking/chapter2.html).

16 Famously, Carroll's Red Queen gave name to an influential evolutionary hypothesis that proposes, more or less, that species need to constantly adapt and evolve in response to the evolutionary changes of other species. Sometimes described as an "arms race" between species, the theory explains the relative permanence of a dynamic equilibrium in which, despite savage competition, the probability of the extinction of particular species remains fairly constant over time. For an interesting discussion of the biological aspects of the connection between the Red Queen hypothesis and the immune system, see http://www.researchgate.net/post/The_Red_Queen_Hypothesis_in_the_ Immune_System.
} 
Edelman, Lee. No Future: Queer Theory and the Death Drive. Durham: Duke University Press, 2004.

Esposito, Roberto. Bios: Biopolitics and Philosophy. Minneapolis: University of Minnesota Press, 2008.

Esposito, Roberto. Immunitas: The Protection and Negation of Life. Cambridge, UK: Polity Press, 2011.

Haraway, Donna. Simians, Cyborgs, and Women: The Reinvention of Nature. New York: Routledge, 1990.

Neocleous, Mark. “War as Peace, Peace as Pacification." Radical Philosophy no. 159 (2010): 8-17.

Neocleous, Mark. Critique of Security. Edinburgh: Edinburgh University Press, 2008.

Puar, Jasbir. Terrorist Assemblages: Homonationalism in Queer Times. Durham: Duke University Press, 2007.

Steininger, Michael. "What's the Fuss over Angela Merkel's bin Laden Comment?" The Christian Science Monitor, May 5, 2011. http://www.csmonitor.com/World/Europe/2011/0505/What-s-the-fuss-over-Angela-Merkel-s-bin-Ladencomment.

Žižek, Slavoj. "Why Only an Atheist Can Be a True Christian." Lecture delivered at Wilson College, Princeton University, on October 12, 2010. http://www.youtube.com/watch?v=Gx3_2lpvZKM. 